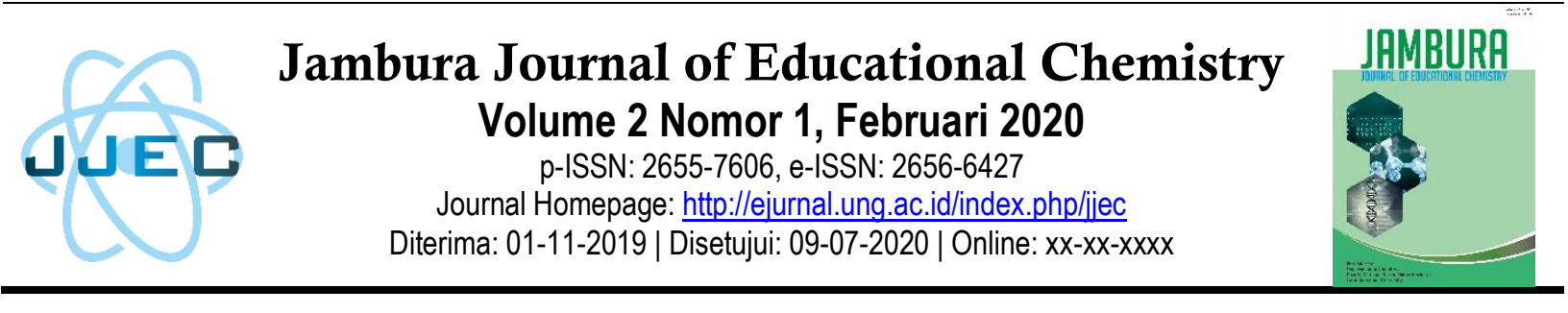

\title{
Analisis Berpikir Kritis Kimia dalam Menyelesaikan Soal Two- Tier Berdasarkan Level Kemampuan Mahasiswa
}

\author{
Alusti Cundo Manik ${ }^{1}$, Siti Suryaningsih², Buchori Muslim³ \\ 1,2,3 Program Studi Pendidikan Kimia, Fakultas Ilu Tarbiyah dan Keguruan, Universitas Islam \\ Negeri Syarif Hidayatullah Jakarta, Jl. Ir. H. Juanda No.95, Ciputat 15412, Indonesia \\ email: ${ }^{1}$ alusticundomanik.acm@gmail.com
}

\begin{abstract}
Abstrak
Berpikir kritis merupakan salah satu tujuan penting dalam pendidikan untuk menghadapi pembelajaran kimia abad ke-21 namun pada umumnya kemampuan tersebut masih rendah. Penelitian ini bertujuan untuk menganalisis kemampuan mahasiswa dalam menyelesaikan setiap soal two-tier berdasarkan indikator kemampuan berpikir kritis kimia dan level akademik mahasiswa. Metode penelitiannya deskriptif kualitatif pada 31 mahasiswa semester 2 tahun ajaran 2018/2019 Program Studi Pendidikan Kimia. Subjek dibagi atas tiga kelompok yaitu level kemampuan tinggi (14 orang), sedang (10 orang), dan rendah (7 orang). Instrumen yang digunakan berupa tes soal twotier. Pengolahan keabsahan data menggunakan teknik triangulasi (mereduksi data, penyajian data, dan penarikan kesimpulan). Hasil penelitian menunjukkan bahwa mahasiswa baik secara keseluruhan maupun berdasarkan level kemampuan kimia (tinggi, sedang, rendah) sudah memiliki kemampuan menjelaskan suatu konsep kimia (grafik titrasi) namun masih rendah dalam mambandingkan kekuatan asam basa berdasarkan ikatan $\mathrm{O}-\mathrm{H}$ dan keelektronegatifan. Sehingga kemampuan berpikir kritis kimia yang dimiliki mahasiswa mampu mendorong dalam memahami konsep-konsep dasar kimia lebih mendalam agar dapat memberikan pemahaman pada tingkat makroskopis maupun mikroskopis.
\end{abstract}

Kata Kunci: Berpikir kritis, level kemampuan, two-tier

\section{PENDAHULUAN}

Salah satu tujuan penting dalam pendidikan adalah tentang berpikir kritis. Berpikir kritis merupakan kemampuan yang sangat efektif dalam semua aspek kehidupan sehingga dapat digunakan sebagai output dari proses pembelajaran (Romero, Hyvonen, \& Barbera, 2012). Partnership for 21st Century Skills telah mengidentifikasi bahwa untuk menyiapkan pada jenjang pendidikan dan dunia kerja berpikir kritis merupakan salah satu dari beberapa kemampuan yang dibutuhkan oleh mahasiswa. John Dewey menyatakan bahwa berpikir kritis sebagai pertimbangan yang aktif, persistent (terus-menerus) serta teliti terhadap keyakinan dan bentuk pengetahuan yang diterima dari sudut pandang alasan-alasan yang mendukungnya dan kesimpulan-kesimpulan lanjutan yang menjadi kecenderungannya (C. \& Black, 2006). Dalam konteks pembelajaran kimia berpikir kritis merupakan kemampuan yang harus dikembangkan dan dikuasai oleh mahasiswa. Berpikir kritis merupakan berpikir logis dan masuk akal yang difokuskan pada pengambilan keputusan tentang apa yang dipercaya dan apa yang dilakukan (Gotoh, 2016). Keterampilan berpikir kritis dalam proses pembelajaran kimia dibutuhkan untuk menganalisis gejala-gejala maupun fenomenafenomena yang muncul.

Permasalahan yang sering terjadi dalam pembelajaran kimia adalah kemampuan berpikir kritis setiap individu berbeda-beda, tergantung pada latihan yang sering dilakukan untuk mengembangkan berpikir kritis masing-masing individu (Ren \& Wang, 2018). Kenyataan, banyak 
mahasiswa yang menunjukkan bahwa dalam mempelajari pelajaran kimia mereka masih kurang mengembangkan kemampuan berpikir kritis dan masih teoritis (Fakhriyah, 2014). Antusias mahasiswa dalam menjawab pertanyaan yang diajukan oleh dosen masih terbatas secara teori belum menunjukkan pengembangan yang sesuai dengan potensi mereka (Adair \& Jaeger, 2016). Selain itu, terlihat bahwa mahasiswa masih sulit dalam bekerja kelompok, berkomunikasi, memecahkan masalah, serta belum bisa mengambil keputusan yang tepat sebagai solusi dari suatu permasalahan. Sehingga, berpikir kritis sangat diperlukan ketika memahami informasi yang akan digunakan untuk menciptakan sebuah ide (Firdaus et.al, 2015).

Konsep dasar dari berpikir kritis adalah interpretation, analysis, inference, evaluation, explanation dan kepercayaan diri (Facione, 2013). Sedangkan berpikir kritis menurut (Ennis, 1996) terdiri dari fokus (focus), alasan (reasons), kesimplan (inference), situasi (situation), kejelasan (clarity), dan pemeriksaan secara menyeluruh (overview). Kemudian (Garrison, Anderson, \& Archer, 2009) membagi empat keterampilan berpikir kritis berupa trigger event (cepat tanggap), exploration (explorasi), integration (integrasi), resolution (mengusulkan). Sehingga, keterampilan berpikir kritis sangat diperlukan untuk mencoba memahami informasi yang akan digunakan dalam mencetuskan ide atau gagasan (Lorentzen, 2013).

Terdapat beberapa tipe model dalam pengembangan instrumen seperti (Shidiq A, Masykuri, M., \& Van Hayus, E., 2014) mengembangkan sebuah instrumen tes untuk menganalisis kemampuan berpikir mahasiswa yang dikenal sebagai two-tier diagnostic test. Sesuai dengan namanya, setiap butir soal pada instrumen two-tier diagnostic test terdiri dari dua bagian atau disebut dengan tingkatan (tier) yaitu pilihan jawaban dari soal pada tier pertama dan pilihan alasan dari jawaban yang dipilih berupa tier kedua. Tahapan dalam penyusunan two-tier diagnostic test mengacu pada tahapan yang dilakukan oleh (Treagust, 1988). Tahapan tersebt terdiri dari: 1) Tahap pertama dilakukan penentuan isi materi atau dalam ini dilakukan tentang analisis konsep. Analisis konsep dapat diartikan sebagai mengidentifikasi konsep-konsep yang penting dalam materi yang diajarkan, menyusun konsep serta menganalisis sifat konsep, kedudukan konsep dan contoh yang berkaitan. 2) Tahap kedua yaitu mengumpulkan informasi tentang kemampuan berpikir kritis mahasiswa diperoleh dari telaah literatur penelitian. 3) Tahap ketiga yaitu pengembangan two-tier test. Pengembangan dimulai dengan membuat kisi-kisi soal sesuai dnegan materi/konsep kimia yang telah dianalisis pada tahap pertama. Kemudian dilanjutkan dengan mengembangkan soal pilihan ganda biasa dalam bentuk one tier (hanya tier berupa jawaban). Kemudian dikembangkan dengan penambahan tier alasan menjadi soal pilihan ganda dalam bentuk two-tier. 4) Tahap keempat yaitu memperbaiki draf two-tier test hingga menjadi two-tier test yang sempurna.

Berdasarkan pernyataan diatas, dapat disimpulkan bahwa berpikir kritis dapat melatih pembelajaran kimia mahasiswa menjadi lebih efektif. Kemampuan berpikir kritis kimia merupakan kemampuan kimia tingkat tinggi yang dapat diukur menggunakan indikator: 1) Interpretation 2) Analysis 3) Inference 4) Evaluation 5) Explanation. Penelitian ini dilakukan untuk menganalisis kemampuan berpikir kritis kimia dalam menyelesaikan soal two-tier berdasarkan level kemampuan mahasiswa. Diharapkan dapat mendiskripsikan dan menganalisis kemampuan berpikir kritis mahasiswa dalam menyelesaikan soal tes two-tier materi kimia berdasarkan indikator kemampuan berpikir kritis kimia dan level kemampuan mahasiswa.

\section{METODE PENELITIAN Jenis Penelitian}

Penelitian ini menggunakan metode deskriptif kualitatif yang berupa analisis data. Analisis data dilakukan dengan mengkaji dokumendokumen hasil tes two-tier. Adapun jenis penelitian yang digunakan dalam penelitian ini adalah penelitian kualitatif. Dimana penelitian kualitatif merupakan sebuah penelitian yng bercirikan informasi yang berupa ikatan konteks yang akan menggiring pada pola-pola atau teori yang akan menjelaskan suatu fenomena (Sumantri, G.R, 2004). 


\section{Waktu dan Tempat Penelitian}

Penelitian ini dilakukan pada bulan mei 2019 di kelas B Semester 2 Pendidikan Kimia UIN Syarif Hidayatullah Jakarta.

\section{Target/Subjek Penelitian}

Populasi pada penelitian ini adalah mahasiswa semester 2 Pendidikan Kimia UIN Syarif Hidayatullah Jakarta sebanyak 64 mahasiswa. Sedangkan sampel yang diambil yaitu mahasiswa kelas B semester 2 tahun ajaran 2018/2019 berjumlah 31 mahasiswa. Pengambilan sampel dalam penelitian ini dilakukan dengan menggunakan teknik random sampling. Dimana random sampling merupakan teknik pengambilan sampel secara acak tanpa memperhatikan strata yang ada dalam populasi tersebut (Sugiyono, 2008).

\section{Prosedur}

Prosedur penelitian terdiri dari tahap perencanaan, tahap pelaksanaan, dan tahap analisis data. Dimana tahap perencanaan dilakukan dengan studi literatur dan menyusun soal two-tier. Pada tahap pelaksanaan dengan memberikan soal dan pengambilan data. Sedangkan pada tahap analisis data melakukan analisis data dan membuat kesimpulan penelitian.

\section{Data, Intrumen, dan Teknik Pengumpulan Data}

Instrumen yang digunakan pada penelitian ini berupa soal tes two-tier yang divalidasi oleh 2 orang dosen kimia berjumlah 20 soal. Penilaian instrumen tes soal two-tier yang mana jawaban benar mendapat skor $=1$, yang menjawab salah skor $=0$, dan jika dalam soal two-tier (pilihan jawaban dan alasan benar) mendapat skor $=2$ yang diadaptasi dari (Sadhu, 2018). Instrumen keterampilan berpikir kritis mencakup 5 indikator keterampilan berpikir kritis diadaptasi dari (Facione, 2013).

\section{Teknik Analisis Data}

Teknik analisis yang digunakan berupa analisis kuantitatif dan kualitatif. Dimana teknik kuantitatif digunakan dalam mengelompokkan level kemampuan berpikir kritis mahasiswa. Teknik analisis data yang digunakan pada peneitian ini menggunakan data statistik dengan perhitungan mean, persentase, nilai maksimum, nilai minimum, dan standar deviasi. Hasil penelitian kemudian di interpretasikan yang berpedoman pada penskoran menurut Riduwan (2012) yang disajikan pada Tabel 1. Sedangkan teknik analisis kualitatif digunakan dalam menganalisis data dari soal tes two-tier dari masing-masing level kemampuan berpikir kritis mahasiswa.

Tabel 1. Kategori Level Kemampuan Berpikir Kritis Mahasiswa

\begin{tabular}{cc}
\hline Interval Skor & Kategori \\
\hline $81-100$ & Sangat Baik \\
$61-80$ & Baik \\
$41-60$ & Cukup \\
$21-40$ & Kurang \\
$0-20$ & Sangat Kurang \\
\hline
\end{tabular}

\section{HASIL DAN PEMBAHASAN}

Hasil penelitian terdiri dari pemaparan jawaban subjek penelitian secara tertulis. Tabel 2 berikut merupakan paparan kemampuan berpikir kritis mahasiswa dalam menyelesaikan soal tes twotier berdasarkan indikator dan level kemampuan kimia mahasiswa

Tabel 2. Kemampuan Berpikir Kritis Kimia Mahasiswa Berdasarkan Indikator Kemampuan Berpikir dan Level Kemampuan

\begin{tabular}{lcccccc}
\hline Level & \multicolumn{7}{c}{ Indikator 1 } \\
\cline { 2 - 7 } Kemampuan & B & \% & ST & \% & S & \% \\
\hline Tinggi & 4 & $28,57 \%$ & 10 & $71,43 \%$ & 0 & $0 \%$ \\
\hline Sedang & 1 & $10 \%$ & 5 & $50 \%$ & 4 & $40 \%$ \\
\hline Rendah & 0 & $0 \%$ & 1 & $14,2 \%$ & 6 & $85,8 \%$ \\
\hline Jumlah & 5 & $16,13 \%$ & 16 & $51,61 \%$ & 10 & $32,26 \%$ \\
\hline
\end{tabular}




\begin{tabular}{|c|c|c|c|c|c|c|}
\hline \multirow{2}{*}{$\begin{array}{c}\text { Level } \\
\text { Kemampuan }\end{array}$} & \multicolumn{6}{|c|}{ Indikator 2} \\
\hline & B & $\%$ & ST & $\%$ & $\mathbf{S}$ & $\%$ \\
\hline Tinggi & 3 & $21,42 \%$ & 11 & $78,58 \%$ & 0 & $0 \%$ \\
\hline Sedang & 0 & $0 \%$ & 10 & $100 \%$ & 0 & $0 \%$ \\
\hline Rendah & 0 & $0 \%$ & 3 & $42,85 \%$ & 4 & $57,5 \%$ \\
\hline Jumlah & 3 & $9,67 \%$ & 24 & $77,42 \%$ & 4 & $12,9 \%$ \\
\hline Level & \multicolumn{6}{|c|}{ Indikator 3} \\
\hline Kemampuan & B & $\%$ & ST & $\%$ & $\mathbf{S}$ & $\%$ \\
\hline Tinggi & 1 & $7,14 \%$ & 9 & $64,28 \%$ & 4 & $28,57 \%$ \\
\hline Sedang & 2 & $20 \%$ & 2 & $20 \%$ & 6 & $60 \%$ \\
\hline Rendah & 0 & $0 \%$ & 1 & $14,2 \%$ & 6 & $85,8 \%$ \\
\hline Jumlah & 3 & $9,67 \%$ & 12 & $38,7 \%$ & 16 & $51,61 \%$ \\
\hline Level & \multicolumn{6}{|c|}{ Indikator 4} \\
\hline Kemampuan & $\mathbf{B}$ & $\%$ & ST & $\%$ & $\mathbf{S}$ & $\%$ \\
\hline Tinggi & 1 & $7,14 \%$ & 10 & $71,4 \%$ & 3 & $21,42 \%$ \\
\hline Sedang & 0 & $0 \%$ & 6 & $60 \%$ & 4 & $40 \%$ \\
\hline Rendah & 0 & $0 \%$ & 2 & $28,57 \%$ & 5 & $71,43 \%$ \\
\hline Jumlah & 1 & $3,22 \%$ & 18 & $58 \%$ & 10 & $32,26 \%$ \\
\hline Level & \multicolumn{6}{|c|}{ Indikator 5} \\
\hline Kemampuan & B & $\%$ & ST & $\%$ & $\mathbf{S}$ & $\%$ \\
\hline Tinggi & 5 & $35,72 \%$ & 8 & $57,14 \%$ & 1 & $7,14 \%$ \\
\hline Sedang & 1 & $10 \%$ & 2 & $20 \%$ & 7 & $70 \%$ \\
\hline Rendah & 0 & $0 \%$ & 3 & $42,85 \%$ & 4 & $57,5 \%$ \\
\hline Jumlah & 6 & $19,35 \%$ & 13 & $41,93 \%$ & 12 & $38,7 \%$ \\
\hline
\end{tabular}

Keterangan:

Indikator 1 : (Interpretation) kemampuan dalam memahami atau menggambarkan kembali makna informasi atau pesan yang diterimanya

Indikator 2 : (Analysis) merupakan mengamati atau menguraikan informasi yang diterima secara detail untuk dikaji lebih lanjut

Indikator 3 : (Inference) merupakan kemampuan membuat kesimpulan berdasarkan unsur-unsur

Indikator $4 \quad$ : (Evaluation) merupakan suatu kemampuan dalam melakukan penelitian dengan cara mengukur atau membandingkan

Indikator $5 \quad$ : (Explanation) merupakan menjelaskan suatu proses atau informasi dan fenomena

B : Menjawab benar (skor 2)

ST : Menjawab benar pilihan/alasan saja (skor 1)

S : Menjawab salah (skor 0)

Berdasarkan Tabel 2, secara keseluruhan jumlah mahasiswa yang menjawab benar paling banyak pada indikator 5 sebanyak 6 mahasiswa $(19,35 \%)$. Sedangkan jumlah mahasiswa yang menjawab benar paling sedikit adalah pada indikator 4 yaitu 1 mahasiswa $(3,22 \%)$. Hal ini mengindikasikan bahwa mahasiswa sudah mampu untuk menjelaskan suatu proses, informasi atau fenomena (Javed, M., Nawaz, M. A., \& Qurat-ulain, A., 2015). Selanjutnya, sebagian besar mahasiswa belum memiliki kemampuan dalam melakukan penilaian dengan cara mengukur atau membandingkan.

Berdasarkan lembar jawaban mahasiswa peneliti dapat menganalisis bahwa sebagian besar tidak dapat menyelesaikan soal indikator 1 dengan benar dikarenakan oleh: 1) mahasiswa tidak mampu membaca grafik titrasi secara benar; 2) mahasiswa tidak dapat menentukan pada $\mathrm{pH}$ berapa titik ekuivalen dan titik akhir terjadi; 3) Mahasiswa tidak dapat menentukan konsep dari asam basa yang dapat merubah warna saat terjadi titrasi. Sedangkan 
pada indikator 2 mahasiswa tidak mampu menyelesaikan soal dengan benar dikarenakan: 1) mahasiswa belum mampu memahami konsep kimia asam basa dalam kehidupan sehari- hari; 2) sebagian mahasiswa mampu dalam menentukan jawaban yang disajikan namun belum mampu memilih alasan dengan tepat. Menurut (Widiyowati, 2015) indikator 2 (analysis) memiliki tingkat kesulitan yang memang lebih tinggi dari pada indiktor yang lainnya.

Pada indikator 3 mahasiswa belum mampu menyelesaikan soal dengan benar dikarenakan: 1) mahasiswa kurang mampu memahami konsep kimia asam basa dengan benar saat diminta memberikan kesimpulan dari salah satu contoh aplikasi asam basa dalam kehidupan sehari-hari; 2) sebagian mahasiswa sudah faham tentang konsep asam basa berdasarkan $K a$ atau $K b$. Sedangkan pada indikator 4 mahasiswa belum mampu menyelesaikan soal dengan benar dikarenakan: 1) mahasiswa tidak dapat membandingkan suatu sebab akibat dari permasalahan asam basa dalam kehidupan sehari-hari; 2) mahasiswa kurang mampu menelaah hubungan antara $K a$ dan $K b$ dalam asam basa pada obat-obatan. Berdasarkan hasil penelitian dari (Widiyowati, 2015) bahwa pada indikator 3 dan 4 kemampuan mahasiswa masuk dalam kategori baik. Karena kedua indikator tersebut memiliki tingkat kesulitan sedang sehingga sangat sulit.

Sedangkan untuk indikator 5 peneliti menemukan hampir semua bisa menjawab pilihan maupun alasan yang diberikan. Perolehan hasil analisis pada indikator 5, sesuai dengan penelitian dari (Widiyowati, 2015) bahwa indikator explanation termasuk dalam kategori sangat baik. Hal ini bisa terjadi karena tingkat kesulitan soal belum terlalu tinggi hanya cenderung mengamati kemudian menjelaskan informasi yang diperoleh dari peristiwa hingga dalam bentuk data (Wiyoko, T., 2019). Hal ini mengindikasikan bahwa mahasiswa sudah mampu menerangkan atau menjelaskan suatu informasi atau fenomena materi kimia asam basa dengan benar. Hasil uraian diatas, dapat dilihat dari triangulasi hasil jawaban, dan skor yang diperoleh dari mahasiswa berdasarkan level kemampuan sebagai berikut:

\section{A. Analisis Data Mahasiswa Level Kemampuan Tinggi}

Data hasil jawaban soal two-tier dan skor jawaban yang diperoleh mahasiswa berpikir kritis kimia pada level kemampuan tinggi disajikan pada Tabel 3.

Tabel 3. Triangulasi Hasil Jawaban soal two-tier dan Skor Jawaban Mahasiswa Level Kemampuan Tinggi

\begin{tabular}{|c|c|c|}
\hline $\begin{array}{c}\text { Indikator Kemampuan } \\
\text { Berpikir Kritis Kimia }\end{array}$ & Hasil Tes Soal two-tier & Skor Jawaban Mahasiswa \\
\hline \multirow{9}{*}{$\begin{array}{l}\text { (Interpretation) } \\
\text { kemampuan memahami } \\
\text { atau menggambarkan } \\
\text { kembali makna informasi } \\
\text { atau pesan yang } \\
\text { diterimanya }\end{array}$} & 1. Merespon soal tes yang diberikan & 1. Mahasiswa yang memperoleh skor \\
\hline & $\begin{array}{l}\text { 2. Mampu memberikan jawaban } \\
\text { dengan benar namun, belum mampu }\end{array}$ & $\begin{array}{l}2 \text { (benar jawaban dan alasan) ada } 4 \\
\text { orang }\end{array}$ \\
\hline & memberikan alasan dengan benar & Mahasiswa yang memperoleh skor \\
\hline & 3. Mampu membaca grafik titrasi & 1 (benar jawaban saja) \\
\hline & secara benar & ada 6 orang \\
\hline & $\begin{array}{l}\text { 4. Mampu menentukan } \mathrm{pH} \text { dari titik } \\
\text { ekuivalen dan titik akhir pada titrasi }\end{array}$ & $\begin{array}{l}\text { 3. Mahasiswa yang memperoleh skor } \\
1 \text { (benar alasan saja) }\end{array}$ \\
\hline & 5. Mampu memahami konsep asam & ada 4 orang \\
\hline & basa dalam menentukan perubahan & Mahasiswa yang memperoleh skor \\
\hline & warna pada titrasi & $\begin{array}{l}0 \text { (salah jawaban dan alasan) ada } 0 \\
\text { orang }\end{array}$ \\
\hline \multirow{2}{*}{$\begin{array}{l}\text { (Analysis) mengamati atau } \\
\text { menguraikan informasi } \\
\text { yang diterima secara detail } \\
\text { untuk dikaji lebih lanjut }\end{array}$} & $\begin{array}{l}\text { 1. Memberikan respon terhadap soal tes } \\
\text { yang diberikan }\end{array}$ & $\begin{array}{l}\text { 1. Mahasiswa yang memperoleh skor } \\
2 \text { (benar jawaban dan alasan) ada } 3\end{array}$ \\
\hline & $\begin{array}{l}\text { 2. Tidak mengamati secara detail } \\
\text { terhadap soal yang diberikan }\end{array}$ & $\begin{array}{l}\text { orang } \\
\text { 2. Mahasiswa yang memperoleh skor }\end{array}$ \\
\hline
\end{tabular}




\begin{tabular}{|c|c|c|c|}
\hline & 5. & $\begin{array}{l}\text { Belum mampu memahami konsep } \\
\text { asam basa jika diaplikasikan dalam } \\
\text { kehidupan sehari-hari (dalam } \\
\text { pemilihan pupuk berdasarkan pH } \\
\text { tanah) } \\
\text { Lebih mampu memberikan alasan } \\
\text { secara benar dari pada memberikan } \\
\text { jawaban benar } \\
\text { Mampu menguraikan informasi yang } \\
\text { diterima untuk dikaji lebih lanjut }\end{array}$ & $\begin{array}{l}1 \text { (benar jawaban saja) } \\
\text { ada } 5 \text { orang } \\
\text { 3. Mahasiswa yang memperoleh skor } \\
1 \text { (benar alasan saja) } \\
\text { ada } 6 \text { orang } \\
\text { 4. Mahasiswa yang memperoleh skor } \\
0 \text { (salah jawaban dan alasan) ada } 0 \\
\text { orang }\end{array}$ \\
\hline $\begin{array}{l}\text { (Inference) membuat } \\
\text { kesimpulan berdasarkan } \\
\text { unsur-unsur }\end{array}$ & $\begin{array}{l}2 . \\
3 .\end{array}$ & $\begin{array}{l}\text { Memberikan respon terhadap soal tes } \\
\text { yang diberikan } \\
\text { Kurang mampu membuat } \\
\text { kesimpulan dengan tepat } \\
\text { Lebih mampu memberikan alasan } \\
\text { secara benar dari pada memberikan } \\
\text { jawaban benar } \\
\text { Memahami konsep asam basa } \\
\text { berdasarkan } K a \text { atau } K b \text { namun, } \\
\text { kurang memahami pengaplikasian } \\
\text { asam basa dalam kehidupan sehari- } \\
\text { hari (obat aspirin) }\end{array}$ & $\begin{array}{l}\text { 1. Mahasiswa yang memperoleh skor } \\
2 \text { (benar jawaban dan alasan) ada } 1 \\
\text { orang } \\
\text { 2. Mahasiswa yang memperoleh skor } \\
1 \text { (benar jawaban saja) ada } 3 \text { orang } \\
\text { 3. Mahasiswa yang memperoleh skor } \\
1 \text { (benar alasan saja) ada } 6 \text { orang } \\
\text { 4. Mahasiswa yang memperoleh skor } \\
\text { 0 (salah jawaban dan alasan) ada } 4 \\
\text { orang }\end{array}$ \\
\hline $\begin{array}{l}\text { (Evaluation) merupakan } \\
\text { suatu kemampuan dalam } \\
\text { melakukan penelitian } \\
\text { dengan cara mengukur } \\
\text { atau membandingkan }\end{array}$ & 1. & $\begin{array}{l}\text { Memberikan respon terhadap soal tes } \\
\text { yang diberikan } \\
\text { Kurang mampu membandingkan } \\
\text { tingkat keasaman suatu senyawa } \\
\text { berdasarkan nilai } \mathrm{Ka} \\
\text { Mampu memberikan jawaban } \\
\text { dengan benar namun, belum mampu } \\
\text { memberikan alasan dengan benar } \\
\text { Kurang mampu membandingkan } \\
\text { kekuatan asam basa berdasarkan } \\
\text { ikatan O-H dan keelektronegatifan }\end{array}$ & $\begin{array}{l}\text { 1. Mahasiswa yang memperoleh skor } \\
2 \text { (benar jawaban dan alasan) ada } 1 \\
\text { orang } \\
\text { 2. Mahasiswa yang memperoleh skor } \\
1 \text { (benar jawaban saja) ada } 8 \text { orang } \\
\text { 3. Mahasiswa yang memperoleh skor } \\
1 \text { (benar alasan saja) ada } 2 \text { orang } \\
\text { 4. Mahasiswa yang memperoleh skor } \\
\text { 0 (salah jawaban dan alasan) ada } 3 \\
\text { orang }\end{array}$ \\
\hline $\begin{array}{l}\text { (Explanation) merupakan } \\
\text { menerangkan atau } \\
\text { menjelaskan suatu proses } \\
\text { atau informasi dan } \\
\text { fenomena }\end{array}$ & 2. & $\begin{array}{l}\text { Memberikan respon terhadap soal tes } \\
\text { yang diberikan } \\
\text { Mahasiswa mampu menjelaskan } \\
\text { suatu grafik titrasi } \\
\text { Mahasiswa mampu menentukan } \\
\text { perubahan warna yang terjadi dari } \\
\text { hasil titrasi } \\
\text { Tidak semua mahasiswa mampu } \\
\text { memberikan jawaban dengan benar } \\
\text { namun, sudah mampu memberikan } \\
\text { alasan dengan benar }\end{array}$ & $\begin{array}{l}\text { 1. Mahasiswa yang memperoleh skor } \\
2 \text { (benar jawaban dan alasan) ada } 5 \\
\text { orang } \\
\text { 2. Mahasiswa yang memperoleh skor } \\
1 \text { (benar jawaban saja) ada } 5 \text { orang } \\
\text { 3. Mahasiswa yang memperoleh skor } \\
1 \text { (benar alasan saja) ada } 3 \text { orang } \\
\text { 4. Mahasiswa yang memperoleh skor } \\
\text { 0 (salah jawaban dan alasan) ada } 1 \\
\text { orang }\end{array}$ \\
\hline
\end{tabular}

\section{Kesimpulan:}

1. Tidak semua mahasiswa dapat menggambarkan kembali informasi yang diterimanya melalui grafik yang diberikan namun, lebih mampu memberikan jawaban secara benar dari pada memberikan alasan benar

2. Tidak semua mahasiswa dapat menguraikan informasi yang diterima untuk dikaji lebih lanjut walaupun lebih mampu memberikan alasan secara benar dari pada memberikan jawaban benar

3. Mahasiswa belum bisa membuat kesimpulan dengan benar pada soal yang diberikan dikarenakan kurang mengamati secara detail soal yang diberikan 
4. Mahasiswa tidak dapat membandingkan faktor-faktor yang mempengaruhi asam basa sehingga lebih mampu memberikan jawaban benar dari pada alasan benar

5. Sebagian mahasiswa sudah mampu menjelaskan suatu informasi dari grafik titrasi secara benar, baik jawaban maupun alasan.

\section{B. Analisis Data Mahasiswa Level Kemampuan Sedang}

Data hasil jawaban soal two-tier dan skor jawaban yang diperoleh mahasiswa berpikir kritis kimia pada level kemampuan sedang disajikan pada Tabel 4.

Tabel 4. Triangulasi Hasil Jawaban soal two-tier dan Skor Jawaban Mahasiswa dari Level Kemampuan Sedang

\begin{tabular}{|c|c|c|}
\hline $\begin{array}{l}\text { Indikator Kemampuan } \\
\text { Berpikir Kritis Kimia }\end{array}$ & Hasil Tes Soal two-tier & Skor Jawaban Mahasiswa \\
\hline $\begin{array}{l}\text { (Interpretation) kemampuan } \\
\text { memahami atau } \\
\text { menggambarkan kembali } \\
\text { makna informasi atau pesan } \\
\text { yang diterimanya }\end{array}$ & $\begin{array}{l}\text { 1. Sebagian mahasiswa tidak } \\
\text { memberikan jawaban } \\
\text { 2. Mampu menentukan pH dari } \\
\text { titik ekuivalen dan titik akhir } \\
\text { pada titrasi namun tidak mampu } \\
\text { memberikan alasan secara tepat }\end{array}$ & $\begin{array}{l}\text { 1. Mahasiswa yang memperoleh skor } 2 \\
\text { (benar jawaban dan alasan) ada } 1 \\
\text { orang } \\
\text { 2. Mahasiswa yang memperoleh skor } 1 \\
\text { (benar jawaban saja) ada } 5 \text { orang } \\
\text { 3. Mahasiswa yang memperoleh skor } 1 \\
\text { (benar alasan saja) ada } 0 \text { orang } \\
\text { 4. Mahasiswa yang memperoleh skor } 0 \\
\text { (salah jawaban dan alasan) ada } 4 \\
\text { orang }\end{array}$ \\
\hline $\begin{array}{l}\text { (Analysis) mengamati atau } \\
\text { menguraikan informasi yang } \\
\text { diterima secara detail untuk } \\
\text { dikaji lebih lanjut }\end{array}$ & $\begin{array}{ll}\text { 1. } & \text { Hanya mampu menentukan } \\
\text { pupuk yang cocok untuk } \\
\text { sampel tanah berdasarkan nilai } \\
\text { pH }\end{array}$ & $\begin{array}{l}\text { 1. Mahasiswa yang memperoleh skor } 2 \\
\text { (benar jawaban dan alasan) ada } 0 \\
\text { orang } \\
\text { 2. Mahasiswa yang memperoleh skor } 1 \\
\text { (benar jawaban saja) ada } 10 \text { orang } \\
\text { 3. Mahasiswa yang memperoleh skor } 1 \\
\text { (benar alasan saja) ada } 0 \text { orang } \\
\text { 4. Mahasiswa yang memperoleh skor } 0 \\
\text { (salah jawaban dan alasan) ada } 0 \\
\text { orang }\end{array}$ \\
\hline $\begin{array}{l}\text { (Inference) membuat } \\
\text { kesimpulan berdasarkan } \\
\text { unsur-unsur }\end{array}$ & $\begin{array}{l}\text { 1. Sebagian mahasiswa tidak } \\
\text { memberikan jawaban } \\
\text { 2. Mahasiswa belum mampu } \\
\text { membat kesimpulan dengan } \\
\text { tepat } \\
\text { 3. Lebih mampu memberikan } \\
\text { jawaban secara benar dari pada } \\
\text { memberikan alasan benar }\end{array}$ & $\begin{array}{l}\text { 1. Mahasiswa yang memperoleh skor } 2 \\
\text { (benar jawaban dan alasan) ada } 2 \\
\text { orang } \\
\text { 2. Mahasiswa yang memperoleh skor } 1 \\
\text { (benar jawaban saja) ada } 2 \text { orang } \\
\text { 3. Mahasiswa yang memperoleh skor } 1 \\
\text { (benar alasan saja) ada } 0 \text { orang } \\
\text { 4. Mahasiswa yang memperoleh skor } 0 \\
\text { (salah jawaban dan alasan) ada } 6 \\
\text { orang }\end{array}$ \\
\hline $\begin{array}{l}\text { (Evaluation) merupakan } \\
\text { suatu kemampuan dalam } \\
\text { melakukan penelitian } \\
\text { dengan cara mengukur atau } \\
\text { membandingkan }\end{array}$ & $\begin{array}{ll}\text { 1. } & \text { Sebagian mahasiswa tidak } \\
\text { memberikan jawaban } \\
\text { 2. } \\
\text { Tidak menyelesaikan soal } \\
\text { dengan benar } \\
\text { 3. } \\
\text { Belum mampu membandingkan } \\
\text { kekuatan asam basa } \\
\text { berdasarkan ikatan O-H dan } \\
\text { keelektronegatifan }\end{array}$ & $\begin{array}{l}\text { 1. Mahasiswa yang memperoleh skor } 2 \\
\text { (benar jawaban dan alasan) ada } 0 \\
\text { orang } \\
\text { 2. Mahasiswa yang memperoleh skor } 1 \\
\text { (benar jawaban saja) ada } 6 \text { orang } \\
\text { 3. Mahasiswa yang memperoleh skor } 1 \\
\text { (benar alasan saja) ada 0 orang } \\
\text { 4. Mahasiswa yang memperoleh skor } 0\end{array}$ \\
\hline
\end{tabular}




\begin{tabular}{|c|c|c|c|c|}
\hline & & $\begin{array}{l}\text { Lebih mampu memilih jawaban } \\
\text { dengan benar dari pada memilih } \\
\text { alasan }\end{array}$ & & $\begin{array}{l}\text { (salah jawaban dan alasan) ada } 4 \\
\text { orang }\end{array}$ \\
\hline $\begin{array}{l}\text { (Explanation) merupakan } \\
\text { menerangkan atau } \\
\text { menjelaskan suatu proses } \\
\text { atau informasi dan fenomena }\end{array}$ & $\begin{array}{l}1 . \\
2 .\end{array}$ & $\begin{array}{l}\text { Sebagian mahasiswa tidak } \\
\text { memberikan jawaban } \\
\text { Hanya sedikit mahasiswa yang } \\
\text { mampu menjelaskan informasi } \\
\text { dari grafik titrasi berdasarkan } \\
\text { warna hasil titrasi }\end{array}$ & $\begin{array}{l}1 . \\
2 . \\
3 . \\
4 .\end{array}$ & $\begin{array}{l}\text { Mahasiswa yang memperoleh skor } 2 \\
\text { (benar jawaban dan alasan) ada } 1 \\
\text { orang } \\
\text { Mahasiswa yang memperoleh skor } 1 \\
\text { (benar jawaban saja) ada } 2 \text { orang } \\
\text { Mahasiswa yang memperoleh skor } 1 \\
\text { (benar alasan saja) ada } 0 \text { orang } \\
\text { Mahasiswa yang memperoleh skor } 0 \\
\text { (salah jawaban dan alasan) ada } 7 \\
\text { orang }\end{array}$ \\
\hline
\end{tabular}

\section{Kesimpulan:}

1. Mahasiswa tidak dapat menggambarkan kembali informasi yang diterimanya melalui grafik yang diberikan namun, lebih mampu memberikan jawaban secara benar dari pada memberikan alasan benar

2. Mahasiswa tidak dapat menguraikan informasi yang diterima secara detail untuk dikaji lebih lanjut walaupun lebih mampu memberikan jawaban dari pada memberikan alasan.

3. Mahasiswa kurang mampu membuat kesimpulan pada soal yang diberikan dikarenakan kurang mengamati secara detail terhadap soal yang diberikan

4. Mahasiswa tidak dapat membandingkan faktor-faktor yang mempengaruhi asam basa sehingga lebih mampu memberikan jawaban benar dari pada alasan benar

5. Mahasiswa belum mampu menjelaskan suatu informasi dari grafik titrasi secara benar, baik jawaban maupun alasan.

C. Analisis Data Mahasiswa Level Kemampuan Rendah

Data hasil jawaban soal two-tier dan skor jawaban yang diperoleh mahasiswa berpikir kritis kimia pada level kemampuan rendah disajikan pada Tabel 5 .

Tabel 5. Triangulasi Hasil Jawaban soal two-tier dan Skor Jawaban Mahasiswa Level Kemampuan Rendah

\begin{tabular}{|c|c|c|c|c|}
\hline $\begin{array}{l}\text { Indikator Kemampuan Berpikir } \\
\text { Kritis Kimia }\end{array}$ & & Hasil Tes Soal two-tier & & Skor Jawaban Mahasiswa \\
\hline $\begin{array}{l}\text { (Interpretation) kemampuan dalam } \\
\text { memahami atau menggambarkan } \\
\text { kembali makna informasi atau pesan } \\
\text { yang diterimanya }\end{array}$ & 1. & $\begin{array}{l}\text { Kebanyakan mahasiswa } \\
\text { tidak memberikan jawaban } \\
\text { Tidak menggambarkan } \\
\text { kembali informasi atau } \\
\text { pesan yang diterimanya } \\
\text { Tidak mampu menentukan } \\
\text { pH dari titik ekuivalen dan } \\
\text { titik akhir pada titrasi }\end{array}$ & $\begin{array}{l}3 . \\
4 .\end{array}$ & $\begin{array}{l}\text { Mahasiswa yang memperoleh } \\
\text { skor } 2 \text { (benar jawaban dan } \\
\text { alasan) ada } 0 \text { orang } \\
\text { Mahasiswa yang memperoleh } \\
\text { skor } 1 \text { (benar jawaban saja) ada } \\
1 \text { orang } \\
\text { Mahasiswa yang memperoleh } \\
\text { skor } 1 \text { (benar alasan saja) ada } 0 \\
\text { orang } \\
\text { Mahasiswa yang memperoleh } \\
\text { skor } 0 \text { (salah jawaban dan } \\
\text { alasan) ada } 6 \text { orang }\end{array}$ \\
\hline $\begin{array}{l}\text { (Analysis) mengamati atau } \\
\text { menguraikan informasi yang diterima } \\
\text { secara detail untuk dikaji lebih lanjut }\end{array}$ & $\begin{array}{l}1 . \\
2 .\end{array}$ & $\begin{array}{l}\text { Kebanyakan mahasiswa } \\
\text { tidak memberikan jawaban } \\
\text { Mahasiswa yang } \\
\text { memberikan jawaban hanya }\end{array}$ & $\begin{array}{l}1 . \\
2 .\end{array}$ & $\begin{array}{l}\text { Mahasiswa yang memperoleh } \\
\text { skor } 2 \text { (benar jawaban dan } \\
\text { alasan) ada } 0 \text { orang } \\
\text { Mahasiswa yang memperoleh }\end{array}$ \\
\hline
\end{tabular}




\begin{tabular}{|c|c|c|c|c|}
\hline & 3. & $\begin{array}{l}\text { pada jawaban pilihan ganda } \\
\text { namun tidak mampu } \\
\text { menentukan alasan } \\
\text { Mahasiswa tidak mampu } \\
\text { menguraikan informasi } \\
\text { secara detail untuk dikaji } \\
\text { lebih lanjut dalam } \\
\text { menentukan pupuk yang } \\
\text { cocok untuk sampel tanah } \\
\text { berdasarkan nilai pH }\end{array}$ & 3. & $\begin{array}{l}\text { skor } 1 \text { (benar jawaban saja) ada } \\
3 \text { orang } \\
\text { Mahasiswa yang memperoleh } \\
\text { skor } 1 \text { (benar alasan saja) ada } 0 \\
\text { orang } \\
\text { Mahasiswa yang memperoleh } \\
\text { skor } 0 \text { (salah jawaban dan } \\
\text { alasan) ada } 4 \text { orang }\end{array}$ \\
\hline $\begin{array}{l}\text { (Inference) kemampuan membuat } \\
\text { kesimpulan berdasarkan unsur-unsur }\end{array}$ & $\begin{array}{l}1 . \\
2 . \\
3 .\end{array}$ & $\begin{array}{l}\text { Mahasiswa tidak } \\
\text { memberikan jawaban } \\
\text { Mahasiswa tidak mampu } \\
\text { membuat kesimpulan secara } \\
\text { tepat dan benar } \\
\text { Mahasiswa tidak memahami } \\
\text { konsep asam basa } \\
\text { berdasarkan } \mathrm{Ka} \text { atau } \mathrm{Kb}\end{array}$ & 4. & $\begin{array}{l}\text { Mahasiswa yang memperoleh } \\
\text { skor } 2 \text { (benar jawaban dan } \\
\text { alasan) ada } 0 \text { orang } \\
\text { Mahasiswa yang memperoleh } \\
\text { skor } 1 \text { (benar jawaban saja) ada } \\
1 \text { orang } \\
\text { Mahasiswa yang memperoleh } \\
\text { skor } 1 \text { (benar alasan saja) ada } 0 \\
\text { orang } \\
\text { Mahasiswa yang memperoleh } \\
\text { skor } 0 \text { (salah jawaban dan } \\
\text { alasan) ada } 6 \text { orang }\end{array}$ \\
\hline $\begin{array}{l}\text { (Evaluation) merupakan suatu } \\
\text { kemampuan dalam melakukan } \\
\text { penelitian dengan cara mengukur atau } \\
\text { membandingkan }\end{array}$ & 1. & $\begin{array}{l}\text { Kebanyakan mahasiswa } \\
\text { tidak memberikan jawaban } \\
\text { Mahasiswa tidak mampu } \\
\text { membandingkan kekuatan } \\
\text { asam basa berdasarkan } \\
\text { ikatan O-H dan } \\
\text { keelektronegatifan } \\
\text { Hanya mampu menjawab } \\
\text { pada pilihan ganda namun } \\
\text { tidak mampu memberikan } \\
\text { alasan dengan tepat }\end{array}$ & 3. & $\begin{array}{l}\text { Mahasiswa yang memperoleh } \\
\text { skor } 2 \text { (benar jawaban dan } \\
\text { alasan) ada } 0 \text { orang } \\
\text { Mahasiswa yang memperoleh } \\
\text { skor } 1 \text { (benar jawaban saja) ada } \\
2 \text { orang } \\
\text { Mahasiswa yang memperoleh } \\
\text { skor } 1 \text { (benar alasan saja) ada } 0 \\
\text { orang } \\
\text { Mahasiswa yang memperoleh } \\
\text { skor } 0 \text { (salah jawaban dan } \\
\text { alasan) ada } 5 \text { orang }\end{array}$ \\
\hline $\begin{array}{l}\text { (Explanation) merupakan } \\
\text { menerangkan atau menjelaskan suatu } \\
\text { proses atau informasi dan fenomena }\end{array}$ & 1. & $\begin{array}{l}\text { Kebanyakan mahasiswa } \\
\text { tidak memberikan jawaban } \\
\text { Mahasiswa tidak mampu } \\
\text { menentukan dan } \\
\text { menjelaskan perubahan } \\
\text { warna yang terjadi dari hasil } \\
\text { titrasi } \\
\text { Mahasiswa memberikan } \\
\text { alasan yang tidak jauh } \\
\text { berbeda dengan peneliti } \\
\text { sajikan namun masih salah }\end{array}$ & 3. & $\begin{array}{l}\text { Mahasiswa yang memperoleh } \\
\text { skor } 2 \text { (benar jawaban dan } \\
\text { alasan) ada } 0 \text { orang } \\
\text { Mahasiswa yang memperoleh } \\
\text { skor } 1 \text { (benar jawaban saja) ada } \\
3 \text { orang } \\
\text { Mahasiswa yang memperoleh } \\
\text { skor } 1 \text { (benar alasan saja) ada } 0 \\
\text { orang } \\
\text { Mahasiswa yang memperoleh } \\
\text { skor } 0 \text { (salah jawaban dan } \\
\text { alasan) ada } 4 \text { orang }\end{array}$ \\
\hline
\end{tabular}

\section{Kesimpulan:}

1. Mahasiswa tidak dapat menggambarkan kembali informasi yang diterimanya melalui grafik yang diberikan namun, baik memberikan jawaban maupun alasan secara benar

2. Mahasiswa tidak dapat menguraikan informasi yang diterima secara detail untuk dikaji lebih lanjut baik dalam memberikan jawaban maupun alasan secara benar

3. Mahasiswa tidak mampu membuat kesimpulan secara benar terhadap soal yang diberikan dikarenakan kurang 
mengamati secara detail terhadap soal yang diberikan

4. Mahasiswa tidak dapat membandingkan faktor-faktor yang mempengaruhi asam basa sehingga tidak mampu memberikan jawaban maupun alasan secara benar Mahasiswa

5. Tidak mampu menjelaskan suatu informasi dari grafik titrasi secara benar.

Berdasarkan tabel di atas dapat disimpulkan bahwa sebagian mahasiswa belum memiliki kemampuan dalam menggambarkan kembali informasi yang diterimanya, memberikan kesimpulan, menjelaskan dari suatu grafik serta membandingkan beberapa konsep kimia. Sesuai dengan penelitian (Cahyono, 2017) yang mengatakan bahwa mahasiswa kurang memiliki kemampuan berpikir kritis karena mereka tidak mencari pengetahuannya sendiri.

Apabila dilihat dari level kemampuan mahasiswa, pada level kemampuan berpikir tinggi paling banyak menjawab benar adalah indikator 5 sebanyak 5 mahasiswa $(35,72 \%)$, Sedangkan mahasiswa yang menjawab benar paling sedikit pada indikator 3 sebanyak 1 mahasiswa $(7,14 \%)$ dan indikator 4 sebanyak 1 orang $(7,14 \%)$. Sedangkan mahasiswa pada level kemampuan sedang, menjawab benar paling banyak pada indikator 3 sebanyak 2 mahasiswa (20,00\%), Sedangkan paling sedikit menjawab benar pada indikator 2 dan 4 sebanyak 0 mahasiswa (0\%). Mahasiswa pada level kemampuan rendah tidak mampu menjawab benar pada kelima indikator. Kemampuan berpikir kritis yang dimiliki mahasiswa dengan nilai tertinggi terdapat pada indikator kelima yaitu explanation (Alatas, 2014).

Dari hasil analisis jawaban dan perolehan skor mahasiswa, peneliti mendapatkan beberapa informasi diantaranya adalah: 1) Pada soal indikator 1 mahasiswa level kemampuan tinggi dan sedang sudah mampu menggambarkan kembali informasi yang diterimanya. Walaupun masih belum mampu dalam menentukan alasan dari suatu persoalan dengan tepat (Carson, 2006). Sedangkan untuk mahasiswa pada level kemampuan rendah tidak mampu menggambarkan kembali informasi yang diterimanya; 2) Soal indikator 2 pada level kemampuan tinggi dan sedang sudah mampu mengamati dan menguraikan suatu informasi yang diterimanya secara detail. Namun belum mampu untuk mengkaji lebih lanjut sehingga kurang tepat dalam menentukan alasan dari suatu persoalan
(Mestre, Docktor, Strand, \& Ross, 2011). Sedangkan untuk mahasiswa pada level kemampuan rendah hanya mampu mengamati dan menguraikan suatu informasi yang diterimanya melalui pilihan jawaban yang diberikan oleh peneliti; 3) Soal indikator 3 mahasiswa level kemampuan tinggi belum mampu dalam membuat kesimpulan secara tepat dan lebih mampu memberikan alasan secara benar dari pada memberikan jawaban benar. Untuk mahasiswa pada level kemampuan sedang mahasiswa belum mampu membuat kesimpulan dengan tepat meskipun lebih mampu memberikan jawaban secara benar dari pada memberikan alasan benar. Sedangkan mahasiswa pada level kemampuan rendah tidak mampu membuat kesimpulan secara tepat baik pada jawaban dan alasan secara benar; 4) Pada soal indikator 4 mahasiswa level kemampuan tingkat tinggi, rendah maupun sedang tidak mampu membandingkan kekuatan asam basa berdasarkan ikatan O-H dan keelektronegatifan; 5) untuk soal indikator 5 mahasiwa pada level kemampuan tingkat tinggi mampu dalam menjelaskan suatu grafik titrasi meskipun banyak mahasiwa yang lebih memilih pilihan jawaban benar dari pada alasan (Heong et al., 2012). Sedangkan pada level kemampuan tingkat sedang dan rendah mahasiswa masih belum mampu menjelaskan suatu grafik titrasi hal ini dikarenakan masih belum benar dalam menentukan pilihan jawaban dan alasan.

\section{KESIMPULAN}

Mahasiswa baik secara keseluruhan maupun berdasarkan level kemampuan kimia (tinggi, sedang, rendah) sudah memiliki kemampuan untuk menjelaskan suatu konsep kimia (grafik titrasi) namun belum mampu mambandingkan kekuatan asam basa berdasarkan ikatan O-H dan keelektronegatifan.

\section{UCAPAN TERIMA KASIH}

Terima kasih peneliti ucapkan kepada Program Studi Pendidikan Kimia UIN Syarif 
Hidayatullah Jakarta yang turut membatu mewujudkan penelitian ini, juga kepada semua pihak yang telah membantu dalam penelitian ini yang tidak bisa disebutkan satu persatu.

\section{DAFTAR PUSTAKA}

Adair, D., \& Jaeger, M. (2016). Incorporating Critical Thinking into an Engineering Undergraduate Learning Environment. International Journal of Higher Education, $5(2)$, 23-39. https://doi.org/10.5430/ijhe.v5n2p23

Alatas, F. (2014). Hubungan Pemahaman Konsep dengan Keterampilan Berpikir Kritis Melalui Model Pembelajaran Treffinger pada Mata Kuliah Fisika Dasar. Edusains, 6(1), 87-99.

Carson, J. (2006). A Problem with Problem Solving: Teaching Thinking without Teaching Knowledge. Mathematics Educator, 17(2), 7-14. Retrieved from http://eric.ed.gov/?q=A+Problem+With+Pro blem+Solving\&id=EJ841561

C., C. W., \& Black, M. (2006). Critical Thinking. An Introduction to Logic and Scientific Method. The Journal of Philosophy, 44(13), 361. https://doi.org/10.2307/2019787

Cahyono, B. (2017). Korelasi Pemecahan Masalah dan Indikator Berfikir Kritis. Phenomenon : Jurnal Pendidikan MIPA, 5(1), 15. https://doi.org/10.21580/phen.2015.5.1.87

Ennis, R.H. (1996). Critical Thinking. New York: Prentice Hall.

Facione, N. C., \& Facione, P. A. (1992). The California critical thinking dispositions inventory test manual. Millbrae: California Academic Press, 44(1), 1-17. https://doi.org/10.2307/27797240

Fakhriyah, F. (2014). Penerapan problem based learning dalam upaya mengembangkan kemampuan berpikir kritis mahasiswa. Jurnal Pendidikan IPA Indonesia, 3(1), 95101. https://doi.org/10.15294/jpii.v3i1.2906

Garrison, D. R., Anderson, T., \& Archer, W. (2009). Critical thinking, cognitive presence, and computer conferencing in distance education. American Journal of Distance Education, 15(1),

$7-23$. https://doi.org/10.1080/08923640109527071

Gotoh, Y. (2016). Development of Critical Thinking Rubric. 13th International
Conference on Cognition and Exploratory Learning in Digital Age.

Heong, Y. M., Yunos, J. M., Othman, W., Hassan, R., Kiong, T. T., \& Mohamad, M. M. (2012). The Needs Analysis of Learning Higher Order Thinking Skills for Generating Ideas. Procedia - Social and Behavioral Sciences, 59(May 2014), 197-203. https://doi.org/10.1016/j.sbspro.2012.09.265

Javed, M., Nawaz, M. A., \& Qurat-ul-ain, A. (2015). Assessing Postgraduate Students' Critical Thinking Ability. I-Manager's Journal on Educational Psychology, 9(2), 19-26. Retrieved from https://search.proquest.com/docview/176373 1604 ? accountid $=14089 \% 5 \mathrm{Cnhttps}: / /$ eu.alma .exlibrisgroup.com/view/uresolver/44UOC_ INST/openurl?genre $=$ article $\&$ atitle $=$ Assessi ng+Postgraduate+Students $\% 27+$ Critical + Th inking +Ability\&author=Javed\%2C+Muham $\operatorname{mad} \% 3 \mathrm{BMuhammad}+$ Ati

Lorentzen, L. (2013). Limiting Behavior of Random Continued Fractions. Constructive Approximation, 38(2), 171-191. https://doi.org/10.1007/s00365-013-9198-y

Mestre, J. P., Docktor, J. L., Strand, N. E., \& Ross, B. H. (2011). Conceptual Problem Solving in Physics. Psychology of Learning and Motivation - Advances in Research and Theory (Vol. 55). Elsevier Inc. https://doi.org/10.1016/B978-0-12-3876911.00009-0

Ren, J., \& Wang, N. (2018). Production-Oriented Approach and Its Implications for the Cultivation of Critical Thinking Skills in College English Instruction in Mainland China. English Language Teaching, 11(5),33.https://doi.org/10.5539/elt.v11n5p3 3

Riduwan. (2012). Belajar Mudah Penelitian Untuk Guru-Karyawan dan Peneliti Pemula. Bandung: Alfabeta.

Romero, M., Hyvonen, P., \& Barbera, E. (2012). Creativity in Collaborative Learning across the Life Span. Creative Education, 03(04), 422-429.

https://doi.org/10.4236/ce.2012.34066

Sadhu, S. (2018). Development and Validation of an Integrated Assessment for Measuring Critical Thinking and Chemical Literacy in Chemical Equilibrium, 11(3), 557-572 
Shidiq, A., Masykuri, M., \& Van Hayus, E. (2014). Pengembangan Instrumen Penilaian TwoTier Multiple Choice Untuk Mengukur Keterampilan Berpikir Tingkat Tinggi (Higher Order Thinking Skills) Pada Materi Kelarutan Dan Hasil Kali Kelarutan Untuk Mahasiswa. Jurnal Pendidikan Kimia, 3(4), 83-92.

Sumantri, G.R. (2004). Memahami Metode Kualitatif. Out-source call center operates in the Moscow region. Elektrosvyaz, 9(5), 26.

Treagust, D. F. (1988). Development and use of diagnostic tests to evaluate students' misconceptions in science. International
Journal of Science Education, 10(2), 159169.

https://doi.org/10.1080/0950069880100204

Widiyowati, I. I. (2015). Hubungan Kemampuan Berpikir Kritis Dengan Respon Mahasiswa Terhadap Penggunaan Model Pembelajaran Advance Organizer Pada Materi Larutan Penyangga. Pancaran, 4(1), 89-104.

Wiyoko, T. (2019). Analisis Profil Kemampuan Berpikir Kritis Mahasiswa PGSD Dengan Graded Response Models Pada Pembelajaran IPA. Indonesian J. Integr. Sci. Education ( IJIS Edu ). 